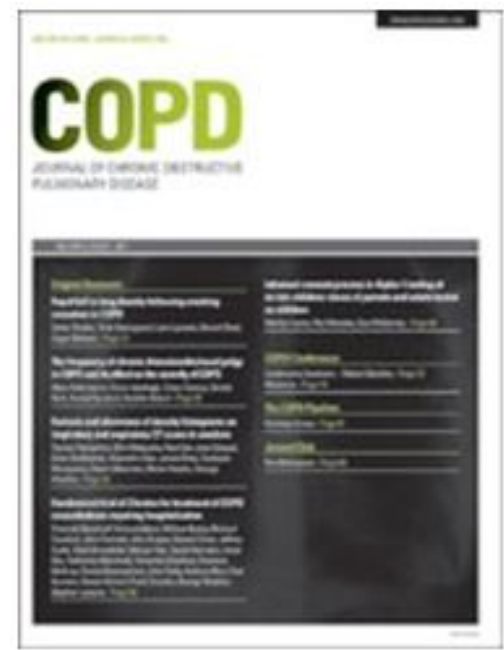

\title{
Ten research questions for improving COPD care in the next decade.
}

\begin{tabular}{|r|l|}
\hline Journal: & COPD: Journal Of Chronic Obstructive Pulmonary Disease \\
\hline Manuscript ID & Draft \\
\hline Manuscript Type: & Perspective \\
\hline Author: & n/a \\
\hline Complete List of Authors: & $\begin{array}{l}\text { Lopez-Campos, Jose Luis; Virgen del Rocio University Hospital, Unidad } \\
\text { Medico-Quirurgica de Enfermedades Respiratorias; } \\
\text { Rodriguez, Diego; Hospital del Mar } \\
\text { Quintana-Gallego, Esther; Virgen del Rocio University Hospital } \\
\text { Martinez-Llorens, Juana; Hospital del Mar } \\
\text { Carrasco Hernandez, Laura; Virgen del Rocio University Hospital } \\
\text { Barreiro, Esther; Hospital del Mar }\end{array}$ \\
\hline Keywords: & $\begin{array}{l}\text { CoPD, Research, diagnosis, pharmacological therapy, vaccines, exercise, } \\
\text { epidemiology }\end{array}$ \\
\hline &
\end{tabular}

\section{SCHOLARONE Manuscripts}




\section{PERSPECTIVE}

Ten research questions for improving COPD care in the next decade.

José Luis López-Campos (1,2), Diego A. Rodríguez (2, 3), Esther Quintana-Gallego

(1,2), Juana Martínez-Llorens (3), Laura Carrasco Hernandez (1,2), Esther Barreiro

Institutions:

1. Unidad Médico-Quirúrgica de Enfermedades Respiratorias. Instituto de Biomedicina de Sevilla (IBiS). Hospital Universitario Virgen del Rocío/Universidad de Sevilla, Spain

2. Centro de Investigación Biomédica en Red de Enfermedades Respiratorias (CIBERES). Instituto de Salud Carlos III, Madrid, Spain

3. Pulmonology Department-Lung Cancer \& Muscle Research Group, IMIM (Hospital del Mar Medical Research Institute), Pompeu Fabra University, Barcelona, Spain

Correspondence: JL Lopez-Campos. Hospital Universitario Virgen del Rocío. Avda. Manuel Siurot, s/n. 41013 Seville, Spain. Tel\&fax: +34955013167. Email: lopezcampos@separ.es 


\begin{abstract}
With the 60th anniversary of the CIBA symposium, it is worth evaluating research questions that should be prioritized in the future. Coming research initiatives can be summarized in 10 main areas. 1. From epidemiology the impact of new forms of electronic cigarettes on prevalence and mortality of COPD will be sought. 2 . The study of the disease endotypes and its relationship phenotypes will have to be unraveled in the next decade. 3. Diagnosis of COPD faces several challenges opening the possibility of a change in the definition of the disease itself. 4. Patients' classification and risk stratification will need to be clarified and reassessed. 5. The asthma-COPD overlap dilemma will have to be clarified and define whether both conditions represent one only chronic airway disease again. 6 . Integrating comorbidities in COPD care will be key in a progressively ageing population to improve clinical care in a chronic care model. 7. Non-pharmacological management have areas for research including pulmonary rehabilitation and vaccines. 8 . Improving physical activity should focus research because of the clear prognostic impact. 9. Pharmacological therapies present several challenges including efficacy and safety issues with current medications and the development of biological therapy. 10. The definition, identification, categorization and specific therapy of exacerbations will also be an area of research development. During the next decade we have a window of opportunity to address these research questions that will put us on the path for precision medicine.
\end{abstract}

Key words: COPD; research; diagnosis; pharmacological therapy; vaccines; exercise; epidemiology 


\section{Introduction}

In this year that we celebrate the 60th anniversary of the CIBA symposium that established the foundations for the definitions we use today for chronic obstructive pulmonary disease (COPD), it is worth evaluating the path taken in order to have a global vision that allows us to prioritize research initiatives for the future. Over the last decades, relevant advances have been achieved in the understanding of COPD. Different aspects including advances in the discussion of the concept of the disease [1], understanding of disease pathogenesis and its relation with the systemic consequences [2], initiatives aiming to identify and improve misdiagnosis [3], the clinical characterization of the disease [4], novel therapeutic strategies with new drugs and initiatives available [5], and the advance in the exacerbation evaluation [6] are some of the key aspects in which the knowledge of the disease has advanced during the last decades. In this perspective article we propose to review the main areas of research in COPD that should be priority research lines for the future, by establishing 10 research questions or areas for research that allow us to continue advancing in the knowledge of this disease to achieve better individualized health care for patients.

\section{Will epidemiologic markers improve in the next decade?}

The impact of epidemiology on medical knowledge and its critical importance in the design of preventive strategies exceeds the individual to place itself in the population, which is the space where changes in health happen. The benefits of preventive actions may have an impact in the community that can be lasting and permanent. The description of disease patterns and the investigation of their causes allows to identify the most exposed or susceptible groups, detect changes in the trend or distribution of health problems, and stratify risks and guide preventive and control actions in an effective and efficient manner. Therefore, epidemiological research results a key element to guide decision-making and planning of prevention and control strategies in the community. 
In COPD all epidemiological markers coincide in showing COPD as a major condition with a high prevalence, high morbidity, with a high impact on the relationship between quality and quantity of life, and constituting a high burden for the health system [7]. The study of the disease prevalence progression and its determinants has represented one of the key aspects of research worldwide [8-11]. In particular, the identification of prevalence determinants including sex, age, tobacco prevalence, and poverty among others, depicts the situation of specific geographical areas to target for an intervention. Current epidemiological studies being carried out [12], will help understanding the progression of the disease in the next decade will provide a window of opportunity to select these geographical areas needing specific actions.

Similarly, the debate on the factors associated with a direct impact on the population, i.e. mortality and disability-adjusted life years, represents another challenge. Although previous studies have shown a decrease in the mortality rates [13], COPD keeps being the $4^{\text {th }}$ cause of mortality worldwide with a slower decreasing pace as compared to other highly prevalent diseases [14]. The understanding of future trends with the advent of new therapeutic strategies will need close surveillance in the coming decade.

In this context, the study of the prevalence of traditional tobacco with cigarettes, other traditional consumptions such as cigar, pipe or hookah, as well as new forms of electronic smoking should be studied in the coming years. The use of alternatives to traditional smoking has increased in the last decade (figure 1) [15]. Available but still incipient evidence indicates that new forms of electronic smoking are a risk factor for developing COPD with potentially worsening its prognosis as shown with traditional cigarettes [16-18]. Notably, from the occurrence of death cases associated with electronic cigarettes, the U.S. Food and Drug Administration has recently released a safety alert recommending against the use of e-cigarette products [19]. With the rise of this forms of electronic smoking, the next few years should also focus on studying its impact on epidemiological markers in COPD. 


\section{Will we be able to unravel the endotype-phenotype black box?}

The study of the disease endotypes and its relationship with the clinical expression has constituted part of the research effort during the last decade [20]. Currently, we know that COPD has different clinical behaviors and that, in turn, they have considerable biological variability that does not always correspond to the clinical presentation [21]. Although various biological pathways have been identified that interact in the pathogenesis of the disease, the relationship between biological phenomena (endotypes) and clinical manifestations (phenotypes) has not been revealed to date. The pattern of behavior seems to be related in such a way that the combination of different biological pathways unequally can result in the same clinical phenotype, and also some clinical presentations may participate from different biological pathways. This may be expected because the clinical manifestation of airway diseases is limited. However, the relationships between the numerous agents described in the pathogenesis of the disease are considerably more numerous (figure 2). Current trends suggest that we may get too late when studying disease pathogenesis and it has been suggested that only by early endotyping at the beginning of the disease could give us a chance to identify disease biological behaviors at early stages [22, 23]. Additionally, the combination of experimental models [24] followed by clinical models should also help addressing this relevant issue. Probably multi-omics and advanced bioinformatics will be able to provide us a more comprehensive and understandable picture that will allow the identification of new therapeutic targets [25] (figure 2). Of note, there are research consortia dedicated to answering this question [26-28] that will shed some light in the next decade.

\section{Will we finally improve diagnosis, or will we change the diagnostic criteria?}

Recent studies suggest that approximately $70 \%$ of COPD worldwide may be underdiagnosed and that between $30 \%$ and $60 \%$ of patients with a previous physician 
diagnosis of COPD do not actually have the disease, being over-diagnosed [3]. The consequences of this incorrect or wrong diagnosis impacts several domains, with many patients receiving pharmacological treatment not needed and with a potential for drugrelated adverse effects, providing health services to the wrong people, subject them to tests, label them as sick or at-risk, tell them to live differently by modifying their daily habits, or insist on monitoring them regularly. Finally, it also impacts on the health system leading to potential extra costs [29]. The reasons behind this high proportion or inaccurate diagnosis are multifactorial, where a low perception of symptoms among the population [30] combined with limited resources [31] and low awareness among physicians [32] combine to give rise to a perfect storm.

Several initiatives have been proposed to increase the suspicion, including validated questionnaires [33, 34], micro-spirometers [35], or simplified on $\mathrm{FEV}_{6}$-based devices like the COPD-6 [36] or Piko-6 [37]. Additionally, another setting worth exploring in the near future is the hospital admission as an opportunity to detect cases. Currently, evidence on the validity and reliability of spirometry performed during admission is scarce due to the heterogeneity and limitations of available studies. However, recent studies have shown the role of spirometry prior to hospital discharge in patients admitted for COPD exacerbation, demonstrating that it is a valid and reproducible method, representing an opportunity to enhance COPD diagnosis [38].

Despite all these initiatives, we must admit that the results are not optimal. It is possible that using a functional evaluation to detect a functional disease such as COPD is a sine-qua-non step. However, recent advances in the importance of lung development in the genesis of the obstruction and its severity [39], as well as the open debate on the importance of the presence of structural lesions (emphysema) without spirometric obstruction [40], open the possibility to a change in the definition of the disease itself, which must be answered in the coming years [41]. 


\section{Will we be able to advance in patients' classification and risk stratification?}

Two main visions of the disease classification and risk stratification have been proposed. A disease stratified by independent variables, as in the Global Initiative for Obstructive Lung Disease (GOLD) document [42], or a clinical phenotype approach, as in the Spanish COPD Guideline (GesEPOC), offer two different perspectives [43]. As recently summarized, both approaches offer advantages and disadvantages [44]. Each approach has relevant issues to be faced in the next decade. Both documents document should improve and validate their risk stratification categories and prognostic impact [45-47]. Additionally, the frequent exacerbator phenotype acknowledged by both documents should be revised [48]. The different versions of the recommendation documents have not changed in relation to the concept of what a frequent exacerbator patient is $[43,49]$. Of note, the current concept of a frequent exacerbator patient required three years of follow-up and identified a group of patients who persisted having exacerbations despite medical treatment [50]. However, the current recommendations documents have simplified this concept, limiting the assessment of the number of exacerbations during the previous year. Since the number of exacerbations is variable over time, it is not clear whether a patient has stopped having exacerbations due to treatment efficacy or to the natural variability of the disease expression.

Another relevant debate is whether lung function should be included in the risk stratification of COPD [51]. The non-consideration of lung function in the follow-up of patients proposed by the GOLD document has been considerable controversy in the scientific community. Future studies should value the contribution of lung function in patient stratification.

Finally, the impact of this stratification on treatment selection needs further scrutiny at the patient level. Future recommendation documents in the next decade should put 
both visions together for an unified global approach and some approaches have already been proposed [52].

\section{Will we be able to solve the asthma-COPD overlap dilemma?}

At least three controversial aspects should be considered regarding asthma-COPD overlap (ACO). First, the concept of ACO is poorly defined. ACO could encompass different situations and may indicate either the presence of both diseases in one patient or a single disease with a peculiar clinical presentation, which are completely different clinical scenarios $[53,54]$. Second, the identification of ACO remains controversial [55]. Several biomarkers have been associated with ACO, including a positive bronchodilator test, bronchial hyper-responsiveness, or peripheral blood or sputum eosinophilia. Here, a positive bronchodilator test or an increased blood eosinophil count have been considered more relevant [43]. Although it is possible that blood eosinophil counts may help clinicians estimate the likelihood of a beneficial preventive response to ICS, there is insufficient evidence to recommend that blood eosinophils should be used to predict future exacerbation risk on an individual basis in COPD patients [56]. Rather, different approaches have been proposed to wisely use blood eosinophils count for treatment selection including the clinical context [57], the persistence over time [58] or the combination with exhaled biomarkers $[59,60]$. Third, since the definition is not settled, there are no clinical trials that have evaluated the efficacy and safety of COPD and asthma-related therapies [61]. In the next decade, it is key that we are able to understand this specific form of COPD and its clinical implications in daily clinical practice. In this debate, one approach aims to combine COPD and asthma spectrum into one only chronic airway disease as already suggested many years ago [62].

\section{Finally integrating comorbidities in COPD care.}

Comorbidities, which are common in patients with COPD, have a great impact on the patients' quality of life and disease prognosis irrespective of the severity of the airway 
obstruction. In keeping with, it has been recently proposed that the comorbidome should be assessed in ambulatory COPD patients [63]. The prevalence of osteoporosis in COPD patients is greater than in non-COPD subjects, thus increasing the risk of vertebral fractures in those patients [64]. Cardiovascular comorbidities are also important in COPD and they are commonly a matter of research even nowadays [65]. Skeletal muscle dysfunction of both respiratory and limb muscle groups is also highly prevalent in patients with COPD [66]. Several factors are involved in the pathophysiology of skeletal muscle dysfunction: factors inherent to COPD and certain comorbidities that also impact on muscle physiology and biology [67]. Furthermore, COPD may also be associated with other respiratory and non-respiratory diseases with an impact on the lungs [68-71]. For instance, advanced COPD may lead to the development of bronchiectasis [68] and may also be associated with Obstructive Sleep Apnea Syndrome [71]. Conditions such as HIV may also favor the development of COPD in smokers probably as a result of inflammatory pattern in the lungs of HIVinfected patients [70]. In the future, patients would probably benefit from an integrated approach considering the comorbidome and the medication associated to improve clinical care. In this sense, a chronic care model has started to get attention [72].

\section{Non-pharmacological management of COPD in the next decade.}

Although we have considerable evidence to establish recommendations on nonpharmacological treatments in COPD [73], the number of aspects that need research is remarkable. First, smoking is COPD is a great challenge [74]. Additionally, there is an ongoing debate about the potential role of electronic cigarettes as a therapeutic approach for smoking cessation. Currently the efficacy/safety profile has not been consistently demonstrated and scientific societies recommends against using this form of tobacco for smoking cessation [16]. With some initial trials with contradictory results [75-77] and a recent FDA safety warning [19], future research should focus on 
demonstrating the potentials and the risks of this new form of tobacco on smoking cessation.

Second, the impact of rehabilitation on COPD-related outcomes has been consistently proven in different domains of the disease [78]. However, real-world implementation is far from being good, with a low percentage of the population with access and with a considerable variability in the indication, resources and procedures [79]. Future research should continue advancing in the validation and implementation of more local rehabilitation programs in the community to make these therapies more at hand for COPD patients $[80,81]$.

In relation with vaccines, two main challenges are to be faced in the coming years. First, to evaluate the impact of Pneumococcal vaccine on the prevention of COPD exacerbations and the prognosis of the disease [82]. Second, the efficacy and safety of other vaccines against common microorganisms related with exacerbations, including Hemophilus and Moraxella [83]. A recent study has shown that The Non-typeable Haemophilus influenzae vaccine had an acceptable safety and reactogenicity profile and good immunogenicity in adults with COPD $[84,85]$. If proven to be effective, the potential impact on the reduction of exacerbations could be notable.

Home therapies should also constitute part of the focus of clinical research in COPD, with two main objectives. First, the titration of long-term oxygen therapy in different clinical circumstances, including sleep, exercise, air travel in patients with and without respiratory insufficiency at rest is a matter worth exploring [86]. Second, the clarification of the indication of home mechanical ventilation in stable COPD represents another challenge [87]. The discrepancy found in previous clinical trials has led systematic reviews and meta-analyses to suggest that, although some patients appear to benefit, the effectiveness of HMV in stable COPD remains uncertain [88]. It has been proposed that the variances in the different trial outcomes may be due to the different underlying pathophysiological mechanisms (figure 3) [89]. Therefore, we need to establish a 
consensual unified systematic diagnostic approach for these patients in order to understand the mechanical behaviour before initiating HMV. This initiative must then be followed by clinical trials designed to evaluate the impact of HMV in these pathophysiological mechanisms. Recently, a position document from the Eurpean Respiratory Society has established current knowledge and recommendations and identified areas of interest for research in the future [90].

Finally, another relevant aspect of COPD unfortunately not very well covered in many countries is palliative care. In a world in which oncological palliative care is part of the usual clinical practice, it is incomprehensible how palliative care in end-stage chronic respiratory diseases can be so sparsely considered by many health care providers [91]. A recent survey in Spain has revealed several deficiencies in the management of these cases and their support to the family [92]. Specifically, another neglected aspect of advanced COPD care is in relation with the evaluation of the social aspects of the disease, preventing the system to provide a comprehensive and efficient care if not considered [93]. Further research is needed to improve our understanding on palliative care provision in advanced COPD [94].

\section{Improving physical activity in the XXI century.}

Physical activity should be promoted in patients with chronic respiratory diseases, given its implications in quality of life and disease prognosis [95]. Poorer quality of life and greater mortality have been demonstrated in inactive COPD patients as compared to more active patients $[96,97]$. Moreover, the risk of exacerbations also increases in physically inactive patients $[98,99]$. Muscle performance and adaptation to exercise may favor physical activity in COPD patients [100]. Muscle exercise training, a major component of pulmonary rehabilitation, is a key element in the treatment of patients with COPD $[100,101]$ as it exerts beneficial effects on skeletal muscle performance, while favoring exercise capacity and physical activity in patients with COPD [100-102] in a safely manner [103]. Physical activity can be easily assessed in clinical settings 
using specific questionnaires and other tests, thus they should be implemented in the evaluation of ambulatory patients on routine basis $[95,104-106]$ as well as following hospitalization [102].

\section{Future challenges in pharmacological treatment}

Due to the considerable expansion of therapeutic options and the increase in the knowledge of determinants of disease presentations, research challenges for COPD pharmacological therapies are numerous. In relation with bronchodilators, the antiinflammatory effects of long-acting bronchodilators should be further clarified. Results from multiple in vitro studies as well as those from experimental models of pulmonary disease have demonstrated anti-inflammatory effects of both families of long-acting bronchodilators as well as additive anti-inflammatory effects of agents from these two classes [107]. Future research should now focus on getting data from patients with COPD to explore the real contribution of this effect on clinical outcomes, i.e. exacerbation risk.

In relation with inhaled corticosteroids there are two main topics for research. Firsty, its relationship with lung infections beyond pneumonia. Specifically, the potential increased risk of mycobacterial infection and the determinants in different patient types and social contexts are worth exploring [108]. Second, the potential role of inhaled corticosteroids in the prevention of lung cancer [109] has been recently proposed and needs further research.

The emergence of triple therapy fixed-dose combination in a single inhalation device has led to a change in the use of this triple combination. Although clinical trials give us an idea of the efficacy and safety of these combinations, their application to the daily clinic may present challenges for the clinic on which it would be appropriate to make some reflections. The analysis of effectiveness and safety, as well as its costeffectiveness and its impact on real life will have to lead future clinical research [110]. 
In the development of these combinations there are still points needing clarification. First, there are still numerous clinical outcomes pending exploration. Results such as $\mathrm{FEV}_{1}$ morning 5 minutes post dose, peak $\mathrm{FEV}_{1}$, the area under the curve of 0 to 24 hours of $\mathrm{FEV}_{1}$, total lung capacity, functional residual capacity, residual volume or inspiratory capacity and its impact on dyspnea have not been sufficiently explored or has not been analyzed in clinical trials. Second, there is considerable variability within the results obtained, both between different combinations and within the same combination. From a clinical practice point of view, however, it is necessary to advance the therapeutic response individually according to the clinical profile of the patient [111].

The role of biological therapies in COPD will have to be clarified in the next decade [112]. Currently, clinical trials exploring the efficacy and safety of different biological therapies in COPD have yielded disappointing results. From the early studies [113] to the more recent ones [114], biological therapy has failed to demonstrate consistent improvements in COPD, even in those cases that could potentially benefit from it [115]. The possible exception can be the patient with ACO, in which a possible effect has been shown with omalizumab [116].

Finally, the medical care according to risk level a present a considerably variability in clinical practice [117]. Additionally, a large proportion of COPD patients seen in respiratory clinics have non-complex disease and pulmonology tests are rarely performed [118]. As a consequence, around two thirds of patients seen in specialized outpatient clinics do not need to have their treatment adjusted [119]. In a disease with a considerable variability in the clinical presentation even in the context of a highly selected population from a multinational clinical trial [120], future research should also focus on the debate of personalized medicine to improve medical prescriptions in the real world [121]. 


\section{Exacerbations: rationale for improvement in near future}

Despite current updates on the recommendations' documents for diagnosis, and treatment of COPD exacerbations [122], there are quite a few numbers of controversies regarding exacerbations. From the definition, the differential diagnosis from other mimicking comorbidities and the different types and response to therapies at the patient level, exacerbations represent a challenge for future research.

There will come a time when we can no longer postpone the decision to define an exacerbation [123]. At the end, we will have to agree on a globally accepted definition. This definition may have two approaches, either an active definition based on what an exacerbation is, or a passive definition based on what an exacerbation is not, thus making the definition by exclusion. Similarly, we will need to advance into the understanding on the different exacerbations' types and their relationship with the inflammatory influx in stable COPD. Although some studies identify different exacerbation types, we need to remind that current evidence comes from post-hoc and data modelling analyses [124]. Therefore, there is a palpable need to have ad-hoc prospective analysis aiming to shed some light on this relevant topic.

A third, relevant topic regarding exacerbations is related to the graduation of severity. Although the multidimensional evaluation of the patient with an exacerbation and the inclusion of scales in decision making could improve the quality of care without compromising patient safety [125] and that there are a number of scales validated for the severity of an exacerbation [126], these scales are not yet recommended in current recommendation documents $[42,43]$. The next decade should bring the evidence to be able to use these scales in daily clinical practice both at the hospital and in the community. 


\section{Conclusions}

As can be seen from the aspects mentioned above, the research in COPD gives us an exciting future with a considerable number of questions to answer. As the recently deceased singer Leonard Cohen said in his hit The Future (1992) "Things are going to slide, slide in all directions. Won't be nothing. Nothing you can measure anymore". In the future of COPD, we will have to keep measuring all the relevant aspects mentioned here. During the next decade we have a window of opportunity to address these research questions that will put us on the path of being able to provide our patients with a more predictive and safe medicine that achieves good clinical efficacy from a preventive and personalized perspective making a medicine more participatory in the patient-doctor relationship, leading to precision medicine.

\section{Final declarations}

Funding. None.

Conflicts of interest. Dr. Lopez-Campos reports personal fees and non-financial support from AstraZeneca, grants, personal fees and non-financial support from Boehringer Ingelheim, grants, personal fees and non-financial support from Chiesi, personal fees and non-financial support from CSL Behring, grants, personal fees and non-financial support from Esteve, personal fees and non-financial support from Ferrer, grants, personal fees and non-financial support from GebroPharma, grants, personal fees and non-financial support from GlaxoSmithKline, grants, personal fees and nonfinancial support from Grifols, grants, personal fees and non-financial support from Menarini, grants, personal fees and non-financial support from Novartis, grants, personal fees and non-financial support from Rovi, grants, personal fees and non-financial support from Teva, outside the submitted work. Dr. Quintana Gallego reports grants, personal fees and non-financial support from Vertex, grants, personal fees and non-financial support from Chiesi, grants, personal fees and non-financial support from Novartis, outside the submitted work. Dr. Esther Barreiro has received funds to conduct research from Menarini SA 2018 (Spain), GlaxoSmithKline SA (Spain) 2018, and VIFOR (Switzerland). 


\section{References}

1. Boucher RC. Muco-Obstructive Lung Diseases. N Engl J Med 2019: 380(20): 1941-1953.

2. Barnes PJ, Burney PG, Silverman EK, Celli BR, Vestbo J, Wedzicha JA, Wouters EF. Chronic obstructive pulmonary disease. Nat Rev Dis Primers 2015: 1: 15076.

3. Diab N, Gershon AS, Sin DD, Tan WC, Bourbeau J, Boulet LP, Aaron SD. Underdiagnosis and Overdiagnosis of Chronic Obstructive Pulmonary Disease. Am J Respir Crit Care Med 2018: 198(9): 1130-1139.

4. McDonald VM, Fingleton J, Agusti A, Hiles SA, Clark VL, Holland AE, Marks GB, Bardin PP, Beasley R, Pavord ID, Wark PAB, Gibson PG, participants of the Treatable Traits Down Under International W, Treatable Traits Down Under International Workshop p. Treatable traits: a new paradigm for 21 st century management of chronic airway diseases: Treatable Traits Down Under International Workshop report. Eur Respir J 2019: 53(5).

5. $\quad$ Singh D, Barnes PJ, Stockley R, Lopez Valera MV, Vogelmeier C, Agusti A. Pharmacological treatment of COPD: the devil is always in the detail. Eur Respir $J$ 2018: 51(4).

6. Wedzicha JAEC-C, Miravitlles M, Hurst JR, Calverley PM, Albert RK, Anzueto A, Criner GJ, Papi A, Rabe KF, Rigau D, Sliwinski P, Tonia T, Vestbo J, Wilson KC, Krishnan JAAC-C. Management of COPD exacerbations: a European Respiratory Society/American Thoracic Society guideline. Eur Respir J 2017: 49(3).

7. Maselli DJ, Bhatt SP, Anzueto A, Bowler RP, DeMeo DL, Diaz AA, Dransfield MT, Fawzy A, Foreman MG, Hanania NA, Hersh CP, Kim V, Kinney GL, Putcha N, Wan ES, Wells JM, Westney GE, Young KA, Silverman EK, Han MK, Make BJ. Clinical Epidemiology of COPD: Insights From 10 Years of the COPDGene Study. Chest 2019. 8. Echazarreta AL, Arias SJ, Del Olmo R, Giugno ER, Colodenco FD, Arce SC, Bossio JC, Armando G, Soriano JB, Grupo de estudio EA. Prevalence of COPD in 6 Urban Clusters in Argentina: The EPOC.AR Study. Arch Bronconeumol 2018: 54(5): 260-269.

9. Miravitlles M, Soriano JB, Garcia-Rio F, Munoz L, Duran-Tauleria E, Sanchez G, Sobradillo V, Ancochea J. Prevalence of COPD in Spain: impact of undiagnosed COPD on quality of life and daily life activities. Thorax 2009: 64(10): 863-868.

10. Fang L, Gao P, Bao H, Tang X, Wang B, Feng Y, Cong S, Juan J, Fan J, Lu K, Wang N, Hu Y, Wang L. Chronic obstructive pulmonary disease in China: a nationwide prevalence study. Lancet Respir Med 2018: 6(6): 421-430.

11. Mokdad AH, Ballestros K, Echko M, Glenn S, Olsen HE, Mullany E, Lee A, Khan AR, Ahmadi A, Ferrari AJ, Kasaeian A, Werdecker A, Carter A, Zipkin B,

Sartorius B, Serdar B, Sykes BL, Troeger C, Fitzmaurice C, Rehm CD, Santomauro D, Kim D, Colombara D, Schwebel DC, Tsoi D, Kolte D, Nsoesie E, Nichols E, Oren E, Charlson FJ, Patton GC, Roth GA, Hosgood HD, Whiteford HA, Kyu H, Erskine HE, Huang H, Martopullo I, Singh JA, Nachega JB, Sanabria JR, Abbas K, Ong K, Tabb K, Krohn KJ, Cornaby L, Degenhardt L, Moses M, Farvid M, Griswold M, Criqui M, Bell M, Nguyen M, Wallin M, Mirarefin M, Qorbani M, Younis M, Fullman N, Liu P, Briant P, Gona P, Havmoller R, Leung R, Kimokoti R, Bazargan-Hejazi S, Hay SI, Yadgir S, Biryukov S, Vollset SE, Alam T, Frank T, Farid T, Miller T, Vos T, Barnighausen T, Gebrehiwot TT, Yano Y, Al-Aly Z, Mehari A, Handal A, Kandel A, Anderson B, Biroscak B, Mozaffarian D, Dorsey ER, Ding EL, Park EK, Wagner G, Hu G, Chen H, Sunshine JE, Khubchandani J, Leasher J, Leung J, Salomon J, Unutzer J, Cahill L, Cooper L, Horino M, Brauer M, Breitborde N, Hotez P, Topor-Madry R, Soneji S, Stranges S, James S, Amrock S, Jayaraman S, Patel T, Akinyemiju T, Skirbekk V, Kinfu Y, Bhutta Z, Jonas JB, Murray CJL. The State of US Health, 1990-2016: Burden of Diseases, Injuries, and Risk Factors Among US States. Jama 2018: 319(14): 1444-1472. 
12. Alfageme I, de Lucas P, Ancochea J, Miravitlles M, Soler-Cataluna JJ, GarciaRio F, Casanova C, Rodriguez Gonzalez-Moro JM, Cosio BG, Sanchez G, Soriano JB. 10 Years After EPISCAN: A New Study on the Prevalence of COPD in Spain -A Summary of the EPISCAN II Protocol. Arch Bronconeumol 2019: 55(1): 38-47. 13. Lopez-Campos JL, Ruiz-Ramos M, Soriano JB. Mortality trends in chronic obstructive pulmonary disease in Europe, 1994-2010: a joinpoint regression analysis. Lancet Respir Med 2014: 2(1): 54-62.

14. Collaborators GBDCRD. Global, regional, and national deaths, prevalence, disability-adjusted life years, and years lived with disability for chronic obstructive pulmonary disease and asthma, 1990-2015: a systematic analysis for the Global Burden of Disease Study 2015. Lancet Respir Med 2017: 5(9): 691-706.

15. Chaffee BW, Couch ET, Gansky SA. Trends in characteristics and multi-product use among adolescents who use electronic cigarettes, United States 2011-2015. PLoS One 2017: 12(5): e0177073.

16. Bals R, Boyd J, Esposito S, Foronjy R, Hiemstra PS, Jimenez-Ruiz CA, Katsaounou P, Lindberg A, Metz C, Schober W, Spira A, Blasi F. Electronic cigarettes: a task force report from the European Respiratory Society. Eur Respir J 2019: 53(2). 17. Scott A, Lugg ST, Aldridge K, Lewis KE, Bowden A, Mahida RY, Grudzinska FS, Dosanjh D, Parekh D, Foronjy R, Sapey E, Naidu B, Thickett DR. Pro-inflammatory effects of e-cigarette vapour condensate on human alveolar macrophages. Thorax 2018: 73(12): 1161-1169.

18. Reinikovaite V, Rodriguez IE, Karoor V, Rau A, Trinh BB, Deleyiannis FW, Taraseviciene-Stewart $L$. The effects of electronic cigarette vapour on the lung: direct comparison to tobacco smoke. Eur Respir J 2018: 51(4).

19. US Food and Drug Administration. E-Cigarette Products: Safety Communication - Due to the Incidents of Severe Respiratory Disease Associated with Use of an ECigarette Product. Available at: https://www.fda.gov/safety/medwatch-safety-alertshuman-medical-products/e-cigarette-products-safety-communication-due-incidentssevere-respiratory-disease-associated-use-e Posted: 30/08/2019.

20. Garudadri S, Woodruff PG. Targeting Chronic Obstructive Pulmonary Disease Phenotypes, Endotypes, and Biomarkers. Ann Am Thorac Soc 2018:

15(Supplement_4): S234-s238.

21. Barnes PJ. Inflammatory endotypes in COPD. Allergy 2019.

22. Petersen $\mathrm{H}$, Vazquez Guillamet R, Meek P, Sood A, Tesfaigzi Y. Early Endotyping: A Chance for Intervention in Chronic Obstructive Pulmonary Disease. Am J Respir Cell Mol Biol 2018: 59(1): 13-17.

23. Borras-Santos A, Garcia-Aymerich J, Soler-Cataluna JJ, Vigil Gimenez L, Gea Guiral J, Rodriguez Chiaradia D, Pascual-Guardia S, Marcos Rodriguez PJ, Alvarez Martinez CJ, Casanova Macario C, Lopez-Campos JL, Carrasco Hernandez L, Martinez-Gonzalez C, Santos-Perez S, Peces-Barba G, Molina Paris J, Roman Rodriguez M, Barbera JA, Faner R, Agusti A, Cosio BG, en representacion del Grupo Investigador del estudio EC. Determinants of the Appearance and Progression of Early-Onset Chronic Obstructive Pulmonary Disease in Young Adults. A Case-Control Study with Follow-up. Arch Bronconeumol 2019: 55(6): 312-318.

24. Perez Rial S, Peces-Barba G. Do Experimental COPD Models Make Sense? Arch Bronconeumol 2019: 55(2): 65-66.

25. Li CX, Wheelock CE, Skold CM, Wheelock AM. Integration of multi-omics datasets enables molecular classification of COPD. Eur Respir J 2018: 51(5). 26. Gea J, Pascual S, Castro-Acosta A, Hernandez-Carcereny C, Castelo R, Marquez-Martin E, Monton C, Palou A, Faner R, Furlong LI, Seijo L, Sanz F, Tora M, Vilaplana C, Casadevall C, Lopez-Campos JL, Monso E, Peces-Barba G, Cosio BG, Agusti A, en representacion del grupo B, Anexo. Miembros del grupo B. The BIOMEPOC Project: Personalized Biomarkers and Clinical Profiles in Chronic Obstructive Pulmonary Disease. Arch Bronconeumol 2019: 55(2): 93-99. 
27. Verde Z, Santiago C, Chicharro LM, Bandres F, Gomez-Gallego F, Rodriguez Gonzalez-Moro JM, de Lucas P. Association of HTR2A-1438G/A Genetic Polymorphism With Smoking and Chronic Obstructive Pulmonary Disease. Arch Bronconeumol 2019: 55(3): 128-133.

28. Reddel HK, Gerhardsson de Verdier M, Agusti A, Anderson G, Beasley R, Bel EH, Janson C, Make B, Martin RJ, Pavord I, Price D, Keen C, Gardev A, Rennard S, Svereus A, Bansal AT, Brannman L, Karlsson N, Nuevo J, Nyberg F, Young SS, Vestbo J. Prospective observational study in patients with obstructive lung disease: NOVELTY design. ERJ Open Res 2019: 5(1).

29. Fernandez-Villar A, Soriano JB, Lopez-Campos JL. Overdiagnosis of COPD: precise definitions and proposals for improvement. Br J Gen Pract 2017: 67(657): 183184.

30. Riesco Miranda JA, Marca-Frances G, Jimenez-Ruiz CA. Perception and Awareness of chronic obstructive pulmonary disease, Chronic Bronchitis and Pulmonary Emphysema in the Spanish Urban Population. Arch Bronconeumol 2018: 54(6): 352-353.

31. Abad-Arranz M, Moran-Rodriguez A, Mascaros Balaguer E, Quintana Velasco C, Abad Polo L, Nunez Palomo S, Gonzalvez Rey J, Fernandez Vargas AM, Hidalgo Requena A, Helguera Quevedo JM, Garcia Pardo M, Lopez-Campos JL. Quantification of inaccurate diagnosis of COPD in primary care medicine: an analysis of the $\mathrm{COACH}$ clinical audit. Int J Chron Obstruct Pulmon Dis 2019: 14: 1187-1194.

32. Mohigefer J, Calero-Acuna C, Marquez-Martin E, Ortega-Ruiz F, LopezCampos JL. Understanding of COPD among final-year medical students. Int J Chron Obstruct Pulmon Dis 2018: 13: 131-139.

33. Spyratos D, Haidich AB, Chloros D, Michalopoulou D, Sichletidis L. Comparison of Three Screening Questionnaires for Chronic Obstructive Pulmonary Disease in the Primary Care. Respiration 2017: 93(2): 83-89.

34. Ruiz MP. Translation and Validation of the Multidimensional Dyspnea-12 Questionnaire. Arch Bronconeumol 2019: 55(1): 64.

35. Schermer TR, Vatsolaki M, Behr R, Grootens J, Cretier R, Akkermans R, Denis $\mathrm{J}$, Poels $\mathrm{P}$, van den Bemt L. Point of care microspirometry to facilitate the COPD diagnostic process in primary care: a clustered randomised trial. NPJ Prim Care Respir Med 2018: 28(1): 17.

36. Kjeldgaard P, Lykkegaard J, Spillemose H, Ulrik CS. Multicenter study of the COPD-6 screening device: feasible for early detection of chronic obstructive pulmonary disease in primary care? Int J Chron Obstruct Pulmon Dis 2017: 12: 2323-2331.

37. Hidalgo Sierra V, Hernandez Mezquita MA, Palomo Cobos L, Garcia Sanchez M, Castellanos RD, Jodra Sanchez S, Cordovilla Perez R, Barrueco Ferrero M. Usefulness of The Piko-6 Portable Device for Early COPD Detection in Primary Care. Arch Bronconeumol 2018: 54(9): 460-466.

38. Fernandez-Villar A, Represas-Represas C, Mouronte-Roibas C, RamosHernandez C, Priegue-Carrera A, Fernandez-Garcia S, Lopez-Campos JL. Reliability and usefulness of spirometry performed during admission for COPD exacerbation. PLoS One 2018: 13(3): e0194983.

39. Belgrave DCM, Granell R, Turner SW, Curtin JA, Buchan IE, Le Souef PN, Simpson A, Henderson AJ, Custovic A. Lung function trajectories from pre-school age to adulthood and their associations with early life factors: a retrospective analysis of three population-based birth cohort studies. Lancet Respir Med 2018: 6(7): 526-534. 40. Karimi R, Tornling G, Forsslund H, Mikko M, Wheelock AM, Nyren S, Skold CM. Differences in regional air trapping in current smokers with normal spirometry. Eur Respir J 2017: 49(1).

41. Celli BR, Agusti A. COPD: time to improve its taxonomy? ERJ Open Res 2018: $4(1)$.

42. Vogelmeier CF, Criner GJ, Martinez FJ, Anzueto A, Barnes PJ, Bourbeau J, Celli BR, Chen R, Decramer M, Fabbri LM, Frith P, Halpin DM, Lopez Varela MV, 
Nishimura M, Roche N, Rodriguez-Roisin R, Sin DD, Singh D, Stockley R, Vestbo J, Wedzicha JA, Agusti A. Global Strategy for the Diagnosis, Management, and Prevention of Chronic Obstructive Lung Disease 2017 Report: GOLD Executive Summary. Arch Bronconeumol 2017: 53(3): 128-149.

43. Miravitlles M, Soler-Cataluna JJ, Calle M, Molina J, Almagro P, Quintano JA, Trigueros JA, Cosio BG, Casanova C, Antonio Riesco J, Simonet P, Rigau D, Soriano JB, Ancochea J. Spanish Guidelines for Management of Chronic Obstructive Pulmonary Disease (GesEPOC) 2017. Pharmacological Treatment of Stable Phase. Arch Bronconeumol 2017: 53(6): 324-335.

44. Lopez-Campos JL, Centanni S. Current Approaches for Phenotyping as a Target for Precision Medicine in COPD Management. COPD 2018: 15(2): 108-117. 45. Golpe R, Suarez-Valor M, Castro-Anon O, Perez-de-Llano LA. Risk Stratification in Chronic Obstructive Pulmonary Disease. Can the Spanish Guidelines be Improved? Arch Bronconeumol 2018: 54(10): 533-535.

46. Pedone C, Giua R, Scichilone N, Bellia V, Antonelli-Incalzi R. GOLD Staging System is Appropriate to Predict Mortality in Older People With Chronic Obstructive Pulmonary Disease. Arch Bronconeumol 2018.

47. Cabrera Lopez C, Casanova Macario C, Marin Trigo JM, de-Torres JP, Torres RS, Gonzalez JM, Polverino F, Divo M, Pinto Plata V, Zulueta J, Callejas FJ, Celli B. Prognostic Validation Using GesEPOC 2017 Severity Criteria. Arch Bronconeumol 2019.

48. Baloira Villar A, Palop Cervera M. Does the Exacerbator Phenotype in Chronic Obstructive Pulmonary Disease Really Exist? Arch Bronconeumol 2018: 54(3): 119120.

49. Kim J, Lee CH, Lee MG, Shin KC, Yoo KH, Lim SY, Na JO, Yoo CG, Jung KS, Lee SD, Kold Ki. Acute Exacerbation According to GOLD 2017 Categories in Patients with Chronic Obstructive Pulmonary Disease. Arch Bronconeumol 2019.

50. Hurst JR, Vestbo J, Anzueto A, Locantore N, Mullerova H, Tal-Singer R, Miller B, Lomas DA, Agusti A, Macnee W, Calverley P, Rennard S, Wouters EF, Wedzicha JA, Evaluation of CLtIPSEI. Susceptibility to exacerbation in chronic obstructive pulmonary disease. N Engl J Med 2010: 363(12): 1128-1138.

51. Golpe R, Suarez-Valor M, Veiga-Teijeiro I, Veres-Racamonde A, Perez-deLlano LA. Should Lung Function Be Included in the Risk Stratification of Chronic Obstructive Pulmonary Disease Proposed by GesEPOC? Arch Bronconeumol 2019. 52. Lopez-Campos JL, Soler-Cataluna JJ, Miravitlles M. Global Strategy for the Diagnosis, Management, and Prevention of Chronic Obstructive Lung Disease 2019 Report: Future Challenges. Arch Bronconeumol 2019.

53. Lopez-Campos JL, Carrasco Hernandez L, Munoz X, Bustamante V, Barreiro E. Current controversies in the stepping up and stepping down of inhaled therapies for COPD at the patient level. Respirology 2018.

54. Perez de Llano L, Cosio BG, Miravitlles M, Plaza V, group Cs. Accuracy of a New Algorithm to Identify Asthma-COPD Overlap (ACO) Patients in a Cohort of Patients with Chronic Obstructive Airway Disease. Arch Bronconeumol 2018: 54(4): 198-204.

55. Alcazar-Navarrete B, Castellano Minan F, Romero Palacios PJ. Clinical Guidelines in Asthma and Chronic Obstructive Pulmonary Disease: How Useful Are They in Clinical Practice? Arch Bronconeumol 2018: 54(3): 117-118.

56. Singh D, Agusti A, Anzueto A, Barnes PJ, Bourbeau J, Celli BR, Criner GJ, Frith P, Halpin DMG, Han M, Lopez Varela MV, Martinez F, Montes de Oca M, Papi A, Pavord ID, Roche N, Sin DD, Stockley R, Vestbo J, Wedzicha JA, Vogelmeier C. Global Strategy for the Diagnosis, Management, and Prevention of Chronic Obstructive Lung Disease: the GOLD science committee report 2019. Eur Respir J 2019: 53(5).

57. Calverley PMA, Tetzlaff K, Vogelmeier C, Fabbri LM, Magnussen H, Wouters EFM, Mezzanotte W, Disse B, Finnigan H, Asijee G, Hallmann C, Watz H. Eosinophilia, 
Frequent Exacerbations, and Steroid Response in Chronic Obstructive Pulmonary Disease. Am J Respir Crit Care Med 2017: 196(9): 1219-1221.

58. Shin SH, Park HY, Kang D, Cho J, Kwon SO, Park JH, Lee JS, Oh YM, Sin DD, Kim WJ, Lee SD, Group KS. Serial blood eosinophils and clinical outcome in patients with chronic obstructive pulmonary disease. Respir Res 2018: 19(1): 134.

59. Alcazar-Navarrete B, Ruiz Rodriguez O, Conde Baena P, Romero Palacios PJ, Agusti A. Persistently elevated exhaled nitric oxide fraction is associated with increased risk of exacerbation in COPD. Eur Respir J 2018: 51(1).

60. Alcazar-Navarrete B, Castellano Minan F, Santiago Diaz P, Ruiz Rodriguez O, Romero Palacios PJ. Alveolar and Bronchial Nitric Oxide in Chronic Obstructive Pulmonary Disease and Asthma-COPD Overlap. Arch Bronconeumol 2018: 54(8): 414419.

61. Perez de Llano L, Lopez-Campos JL, Cosio BG. The post-truth behind the asthma-COPD overlap and the orbit of Mercury: lessons from the CHACOS study. Arch Bronconeumol 2018: 54(4): 175-176.

62. Postma DS, Weiss ST, van den Berge M, Kerstjens HA, Koppelman GH. Revisiting the Dutch hypothesis. J Allergy Clin Immunol 2015: 136(3): 521-529.

63. Figueira Goncalves JM, Garcia Bello MA, Martin Martinez MD, Garcia-Talavera I, Golpe R. Can the COPD-comorbidome Be Applied to All Outpatients With Chronic Obstructive Pulmonary Disease? A Single-center Analysis. Arch Bronconeumol 2019. 64. Gazzotti MR, Roco CM, Pradella CO, Nascimento OA, Porto EF, Adas M, Lazaretti-Castro M, Jardim JR. Frequency of Osteoporosis and Vertebral Fractures in Chronic Obstructive Pulmonary Disease (COPD) Patients. Arch Bronconeumol 2019: 55(5): 252-257.

65. Lopez-Campos JL, Carrasco Hernandez L, Quintana Gallego E. The HeartLung Dilemma in COPD: A Tale of Two Cities. Arch Bronconeumol 2019: 55(4): 185186.

66. Laveneziana $\mathrm{P}$, Albuquerque A, Aliverti A, Babb T, Barreiro E, Dres M, Dube BP, Fauroux B, Gea J, Guenette JA, Hudson AL, Kabitz HJ, Laghi F, Langer D, Luo YM, Neder JA, O'Donnell D, Polkey MI, Rabinovich RA, Rossi A, Series F, Similowski T, Spengler CM, Vogiatzis I, Verges S. ERS statement on respiratory muscle testing at rest and during exercise. Eur Respir J 2019: 53(6).

67. Gea J, Martinez-Llorens J. Muscle Dysfunction in Chronic Obstructive Pulmonary Disease: Latest Developments. Arch Bronconeumol 2019: 55(5): 237-238. 68. Padilla-Galo A, Olveira Fuster C. Bronchiectasis in COPD and Asthma. More Than Just a Coincidence. Arch Bronconeumol 2019: 55(4): 181-182.

69. Martin Guerra JM, Martin Asenjo M, Sanchez Munoz LA, Duenas Gutierrez CJ. Hyponatremia in COPD: a Little Known Complication. Arch Bronconeumol 2018.

70. Fanjul F, Soriano J. Do HIV-Infected Patients Die of Chronic Obstructive Pulmonary Disease in Western Countries? Arch Bronconeumol 2019: 55(7): 390-391.

71. Marin-Oto M, Marin JM. Obstructive Sleep Apnea Syndrome and chronic obstructive pulmonary disease: Overlap or Syndrome. Arch Bronconeumol 2018: 54(10): 499-500.

72. Yeoh EK, Wong MCS, Wong ELY, Yam C, Poon CM, Chung RY, Chong M, Fang $\mathrm{Y}$, Wang HHX, Liang M, Cheung WWL, Chan $\mathrm{CH}$, Zee B, Coats AJS. Benefits and limitations of implementing Chronic Care Model (CCM) in primary care programs: A systematic review. Int J Cardiol 2018: 258: 279-288.

73. Pleguezuelos E, Gimeno-Santos E, Hernandez C, Mata MDC, Palacios L, Pinera P, Molina J, Chiner E, Miravitlles M. Recommendations on non-Pharmacological Treatment in Chronic Obstructive Pulmonary Disease From the Spanish COPD Guidelines (GesEPOC 2017). Arch Bronconeumol 2018: 54(11): 568-575.

74. Carrion Valero F, Paulos Dos Santos S, Celli BR. Smoking In COPD Patients: A New Clinical Phenotype? Arch Bronconeumol 2018: 54(5): 249-250.

75. Hajek P, Phillips-Waller A, Przulj D, Pesola F, Myers Smith K, Bisal N, Li J, Parrott S, Sasieni P, Dawkins L, Ross L, Goniewicz M, Wu Q, McRobbie HJ. A 
Randomized Trial of E-Cigarettes versus Nicotine-Replacement Therapy. N Engl J Med 2019: 380(7): 629-637.

76. Halpern SD, Harhay MO, Saulsgiver K, Brophy C, Troxel AB, Volpp KG. A Pragmatic Trial of E-Cigarettes, Incentives, and Drugs for Smoking Cessation. N Engl J Med 2018: 378(24): 2302-2310.

77. Gomajee R, El-Khoury F, Goldberg M, Zins M, Lemogne C, Wiernik E, LequyFlahault E, Romanello L, Kousignian I, Melchior M. Association Between Electronic Cigarette Use and Smoking Reduction in France. JAMA Intern Med 2019.

78. Charikiopoulou M, Nikolaidis PT, Knechtle B, Rosemann T, Rapti A, Trakada G. Subjective and Objective Outcomes in Patients With COPD After Pulmonary Rehabilitation - The Impact of Comorbidities. Front Physiol 2019: 10: 286.

79. Spruit MA, Pitta F, Garvey C, ZuWallack RL, Roberts CM, Collins EG, Goldstein R, McNamara R, Surpas P, Atsuyoshi K, Lopez-Campos JL, Vogiatzis I, Williams JE, Lareau S, Brooks D, Troosters T, Singh SJ, Hartl S, Clini EM, Wouters EF, Rehabilitation ERS, Chronic C, Physiotherapists Scientific G, American Association of C, Pulmonary R, Assembly ATSPR, the ERSCAt. Differences in content and organisational aspects of pulmonary rehabilitation programmes. Eur Respir J 2014: 43(5): 1326-1337.

80. Arbillaga-Etxarri A, Gimeno-Santos E, Barberan-Garcia A, Balcells E, Benet M, Borrell E, Celorrio N, Delgado A, Jane C, Marin A, Martin-Cantera C, Monteagudo M, Montella N, Munoz L, Ortega P, Rodriguez DA, Rodriguez-Roisin R, Simonet P, ToranMonserrat P, Torrent-Pallicer J, Vall-Casas P, Vilaro J, Garcia-Aymerich J. Long-term efficacy and effectiveness of a behavioural and community-based exercise intervention (Urban Training) to increase physical activity in patients with COPD: a randomised controlled trial. Eur Respir J 2018: 52(4).

81. Nolan CM, Kaliaraju D, Jones SE, Patel S, Barker R, Walsh JA, Wynne S, Man W. Home versus outpatient pulmonary rehabilitation in COPD: a propensity-matched cohort study. Thorax 2019.

82. Figueira Goncalves JM, Garcia Bello MA, Bethencourt Martin N, Diaz Perez D, Perez-Mendez LI. Impact of 13-valent pneumococcal conjugate polysaccharide vaccination on severe exacerbations in patients with chronic obstructive pulmonary disease and established cardiovascular disease. Eur J Intern Med 2019: 63: e14-e16. 83. Van Damme P, Leroux-Roels G, Vandermeulen C, De Ryck I, Tasciotti A, Dozot M, Moraschini L, Testa M, Arora AK. Safety and immunogenicity of non-typeable Haemophilus influenzae-Moraxella catarrhalis vaccine. Vaccine 2019: 37(23): 31133122.

84. Wilkinson TMA, Schembri S, Brightling C, Bakerly ND, Lewis K, MacNee W, Rombo L, Hedner J, Allen M, Walker PP, De Ryck I, Tasciotti A, Casula D, Moris P, Testa M, Arora AK. Non-typeable Haemophilus influenzae protein vaccine in adults with COPD: A phase 2 clinical trial. Vaccine 2019.

85. Leroux-Roels G, Van Damme P, Haazen W, Shakib S, Caubet M, Aris E, Devaster JM, Peeters M. Phase I, randomized, observer-blind, placebo-controlled studies to evaluate the safety, reactogenicity and immunogenicity of an investigational non-typeable Haemophilus influenzae (NTHi) protein vaccine in adults. Vaccine 2016: 34(27): 3156-3163.

86. Mayoralas-Alises S, Carratala JM, Diaz-Lobato S. New Perspectives in Oxygen Therapy Titration: Is Automatic Titration the Future? Arch Bronconeumol 2019: 55(6): 319-327.

87. Murphy PB, Hart N. Home Non-Invasive Ventilation for COPD: How, Who and When? Arch Bronconeumol 2018: 54(3): 149-154.

88. Struik FM, Lacasse Y, Goldstein R, Kerstjens HM, Wijkstra PJ. Nocturnal noninvasive positive pressure ventilation for stable chronic obstructive pulmonary disease. Cochrane Database Syst Rev 2013(6): CD002878. 
89. Lopez-Campos JL, Caballero-Eraso C, Barrot-Cortes E. Home mechanical ventilation for stable COPD in GOLD 2017: What are we ventilating? Respirology 2017: 22(8): 1497-1499.

90. Ergan B, Oczkowski S, Rochwerg B, Carlucci A, Chatwin M, Clini E, Elliott M, Gonzalez-Bermejo J, Hart N, Lujan M, Nasilowski J, Nava S, Pepin JL, Pisani L, Storre JH, Wijkstra P, Tonia T, Boyd J, Scala R, Windisch W. European Respiratory Society Guideline on Long-term Home Non-Invasive Ventilation for Management of Chronic Obstructive Pulmonary Disease. Eur Respir J 2019.

91. Nieto Cano S, Golpe Gomez R, Perez de Llano LA. The Need for Palliative Care in Chronic Respiratory Patients With Non-Malignant Disease. Arch Bronconeumol 2018: 54(1): 57.

92. Ecenarro PS, Iguiniz MI, Tejada SP, Malanda NM, Imizcoz MA, Marlasca LA, Navarrete BA. Management of COPD in End-of-Life Care by Spanish Pulmonologists. COPD 2018: 15(2): 171-176.

93. Fernandez-Garcia S, Represas-Represas C, Ruano-Ravina A, Mosteiro-Anon M, Mouronte-Roibas C, Fernandez-Villar A. Social Profile of Patients Admitted for COPD Exacerbations. A Gender Analysis. Arch Bronconeumol 2019.

94. Fusi-Schmidhauser T, Riglietti A, Froggatt K, Preston N. Palliative Care Provision for Patients with Advanced Chronic Obstructive Pulmonary Disease: A Systematic Integrative Literature Review. COPD 2018: 15(6): 600-611.

95. Rabinovich RA. Physical Activity in COPD. Significance, Prognosis, Measurement and Therapeutic Interventions. Arch Bronconeumol 2018: 54(9): 449450.

96. Garcia-Aymerich J, Serra I, Gomez FP, Farrero E, Balcells E, Rodriguez DA, de Batlle J, Gimeno E, Donaire-Gonzalez D, Orozco-Levi M, Sauleda J, Gea J, RodriguezRoisin R, Roca J, Agusti AG, Anto JM, Phenotype, Course of CSG. Physical activity and clinical and functional status in COPD. Chest 2009: 136(1): 62-70.

97. Lear SA, Hu W, Rangarajan S, Gasevic D, Leong D, lqbal R, Casanova A, Swaminathan S, Anjana RM, Kumar R, Rosengren A, Wei L, Yang W, Chuangshi W, Huaxing L, Nair S, Diaz R, Swidon H, Gupta R, Mohammadifard N, Lopez-Jaramillo P, Oguz A, Zatonska K, Seron P, Avezum A, Poirier P, Teo K, Yusuf S. The effect of physical activity on mortality and cardiovascular disease in 130000 people from 17 high-income, middle-income, and low-income countries: the PURE study. Lancet 2017: 390(10113): 2643-2654.

98. Borras-Santos A, Garcia-Aymerich J, Soler-Cataluna JJ, Vigil Gimenez L, Gea Guiral J, Rodriguez Chiaradia D, Pascual-Guardia S, Marcos Rodriguez PJ, Alvarez Martinez CJ, Casanova Macario C, Lopez-Campos JL, Carrasco Hernandez L, Martinez-Gonzalez C, Santos-Perez S, Peces-Barba G, Molina Paris J, Roman Rodriguez M, Barbera JA, Faner R, Agusti A, Cosio BG. Determinants of the Appearance and Progression of Early-Onset Chronic Obstructive Pulmonary Disease in Young Adults. A Case-Control Study with Follow-up. Arch Bronconeumol 2019: 55(6): 312-318.

99. Ramon MA, Gimeno-Santos E, Ferrer J, Balcells E, Rodriguez E, de Batlle J, Gomez FP, Sauleda J, Ferrer A, Barbera JA, Agusti A, Gea J, Rodriguez-Roisin R, Anto JM, Garcia-Aymerich J. Hospital admissions and exercise capacity decline in patients with COPD. Eur Respir J 2014: 43(4): 1018-1027.

100. Barreiro E. Impact of Physical Activity and Exercise on Chronic Obstructive Pulmonary Disease Phenotypes: The Relevance of Muscle Adaptation. Arch Bronconeumol 2019.

101. Gimeno-Santos E. Pulmonary Rehabilitation and Long-Term Physical Activity in the Chronic Obstructive Pulmonary Disease Patient. Arch Bronconeumol 2019.

102. Ramon MA. Promoting Physical Activity After Hospitalization For Chronic Obstructive Pulmonary Disease Exacerbation. Arch Bronconeumol 2019. 
103. Pleguezuelos E, Guirao L, Moreno E, Samitier B, Ortega P, Vila X, Majo M, Gonzalez MV, Ovejero L, Juanola J, Gomez A, Miravitlles M. Safety of Rehabilitation Program for COPD Patients. Arch Bronconeumol 2018: 54(2): 111-112.

104. Miravitlles M, Troosters T, Janssens W, Ancochea J. Multidisciplinary Perspectives on the Importance of Physical Activity in COPD. Arch Bronconeumol 2019.

105. Soler-Cataluna JJ, Puente Maestu L, Roman-Rodriguez M, Esteban C, Gea J, Bernabeu Mora R, Pleguezuelos Cobo E, Ancochea J, Monteagudo Ruiz G, Garcia Rio F. Creation of the SAQ-COPD Questionnaire to Determine Physical Activity in COPD Patients in Clinical Practice. Arch Bronconeumol 2018: 54(9): 467-475.

106. Cebollero P, Anton M, Hernandez M, Hueto J. Walking Program for Copd Patients: Clinical Impact After Two Years of Follow-up. Arch Bronconeumol 2018: 54(8): 439-440.

107. Profita M, Bonanno A, Montalbano AM, Albano GD, Riccobono L, Siena L, Ferraro M, Casarosa P, Pieper MP, Gjomarkaj M. beta(2) long-acting and anticholinergic drugs control TGF-beta1-mediated neutrophilic inflammation in COPD. Biochim Biophys Acta 2012: 1822(7): 1079-1089.

108. Lee CM, Heo J, Han SS, Moon KW, Lee SH, Kim YJ, Lee SJ, Kwon JW. Inhaled Corticosteroid-Related Tuberculosis in the Real World Among Patients with Asthma and COPD: A 10-Year Nationwide Population-Based Study. J Allergy Clin Immunol Pract 2019: 7(4): 1197-1206 e1193.

109. Seijo LM, Peces-Barba G. Inhaled Corticosteroids and Lung Cancer in COPD. Arch Bronconeumol 2019.

110. Alcazar-Navarrete B, Castellano Minan F, Romero Palacios PJ. The Future of Triple Therapy in chronic obstructive pulmonary disease. Arch Bronconeumol 2018: 54(2): 63-64.

111. Lopez-Campos JL et al. Triple therapy narratvie review. Submitted

112. Gea J. The Future of Biological Therapies in COPD. Arch Bronconeumol 2018 : 54(4): 185-186.

113. Rennard SI, Fogarty C, Kelsen S, Long W, Ramsdell J, Allison J, Mahler D, Saadeh C, Siler T, Snell P, Korenblat P, Smith W, Kaye M, Mandel M, Andrews C, Prabhu R, Donohue JF, Watt R, Lo KH, Schlenker-Herceg R, Barnathan ES, Murray J, Investigators $\mathrm{C}$. The safety and efficacy of infliximab in moderate to severe chronic obstructive pulmonary disease. Am J Respir Crit Care Med 2007: 175(9): 926-934. 114. Pavord ID, Chanez P, Criner GJ, Kerstjens HAM, Korn S, Lugogo N, Martinot JB, Sagara H, Albers FC, Bradford ES, Harris SS, Mayer B, Rubin DB, Yancey SW, Sciurba FC. Mepolizumab for Eosinophilic Chronic Obstructive Pulmonary Disease. $N$ Engl J Med 2017: 377(17): 1613-1629.

115. Criner GJ, Celli BR, Brightling CE, Agusti A, Papi A, Singh D, Sin DD, Vogelmeier CF, Sciurba FC, Bafadhel M, Backer V, Kato M, Ramirez-Venegas A, Wei YF, Bjermer L, Shih VH, Jison M, O'Quinn S, Makulova N, Newbold P, Goldman M, Martin UJ, Galathea, Investigators TS. Benralizumab for the Prevention of COPD Exacerbations. N Engl J Med 2019.

116. Hanania NA, Chipps BE, Griffin NM, Yoo B, Iqbal A, Casale TB. Omalizumab effectiveness in asthma-COPD overlap: Post hoc analysis of PROSPERO. J Allergy Clin Immunol 2019: 143(4): 1629-1633.e1622.

117. Calle Rubio M, Rodriguez Hermosa JL, Soler-Cataluna JJ, Lopez-Campos JL, Alcazar Navarrete B, Soriano JB, Rodriguez Gonzalez-Moro JM, Fuentes Ferrer ME, Miravitlles M, y el Grupo E. Medical Care According to Risk Level and Adaptation to Spanish COPD Guidelines (Gesepoc): The Epoconsul Study. Arch Bronconeumol 2018: 54(5): 270-279.

118. Izquierdo JL, Miravitlles M, Esquinas C, Perez M, Calle M, Lopez Campos JL, Rodriguez Gonzalez-Moro JM, Casanova C, Esteban C, de Lucas P. Characteristics of COPD Patients Managed in Respiratory Medicine Departments in Spain, According to 
GOLD Groups and GesEPOC Clinical Phenotypes. Arch Bronconeumol 2018: 54(11): 559-567.

119. Lopez-Campos JL, Navarrete BA, Soriano JB, Soler-Cataluna JJ, GonzalezMoro JMR, Ferrer MEF, Rubio MC. Determinants of medical prescriptions for COPD care: an analysis of the EPOCONSUL clinical audit. Int $J$ Chron Obstruct Pulmon Dis 2018: 13: 2279-2288.

120. Anzueto A, Calverley PMA, Mueller A, Metzdorf N, Haensel M, Jardim JR, Pizzichini E, Giraldo H, Ramirez-Venegas A, Giugno ER. Demographic Characteristics and Clinical Outcomes in Patients from Latin America Versus the Rest of the World: A TIOSPIR((R)) Post-Hoc Analysis. Arch Bronconeumol 2018: 54(3): 140-148.

121. Soler-Cataluna JJ. Clinical practice guidelines or personalized medicine in chronic obstructive pulmonary disease? Arch Bronconeumol 2018: 54(5): 247-248.

122. Alcazar Navarrete B, Ancochea Bermudez J, Garcia-Rio F, Izquierdo Alonso JL, Miravitlles M, Rodriguez Gonzalez-Moro JM, Soler-Cataluna JJ. Patients with Chronic Obstructive Pulmonary Disease Exacerbations: Recommendations for Diagnosis, Treatment and Care. Arch Bronconeumol 2019.

123. Kim V, Aaron SD. What is a COPD exacerbation? Current definitions, pitfalls, challenges and opportunities for improvement. Eur Respir J 2018: 52(5).

124. Bafadhel M, McCormick M, Saha S, McKenna S, Shelley M, Hargadon B, Mistry V, Reid C, Parker D, Dodson P, Jenkins M, Lloyd A, Rugman P, Newbold P, Brightling $\mathrm{CE}$. Profiling of sputum inflammatory mediators in asthma and chronic obstructive pulmonary disease. Respiration 2012: 83(1): 36-44.

125. Garcia Sanz MT, Gonzalez Barcala FJ. Establishing the Prognosis of COPD Exacerbations Using Risk Scales from the Point of View of the Emergency Department. Arch Bronconeumol 2019.

126. Shafuddin E, Chang CL, Hancox RJ. Comparing severity scores in exacerbations of chronic obstructive pulmonary disease. Clin Respir J 2018: 12(12):

2668-2675. 
Figure 1. Prevalence of past 30-day cigarette use, past 30-day e-cigarette use, and past 30-day use of other products in the National Youth Tobacco Survey, 2011-2015.

\section{A. Females, grades 6-12}

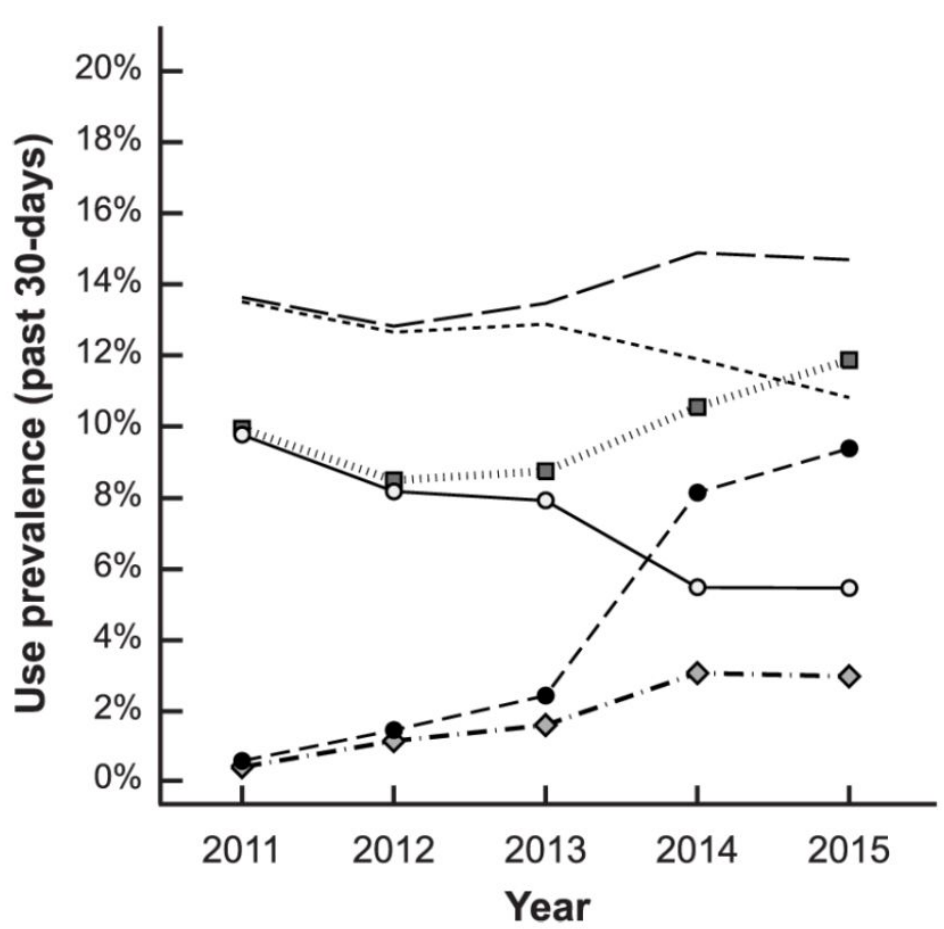

\section{B. Males, grades 6-12}

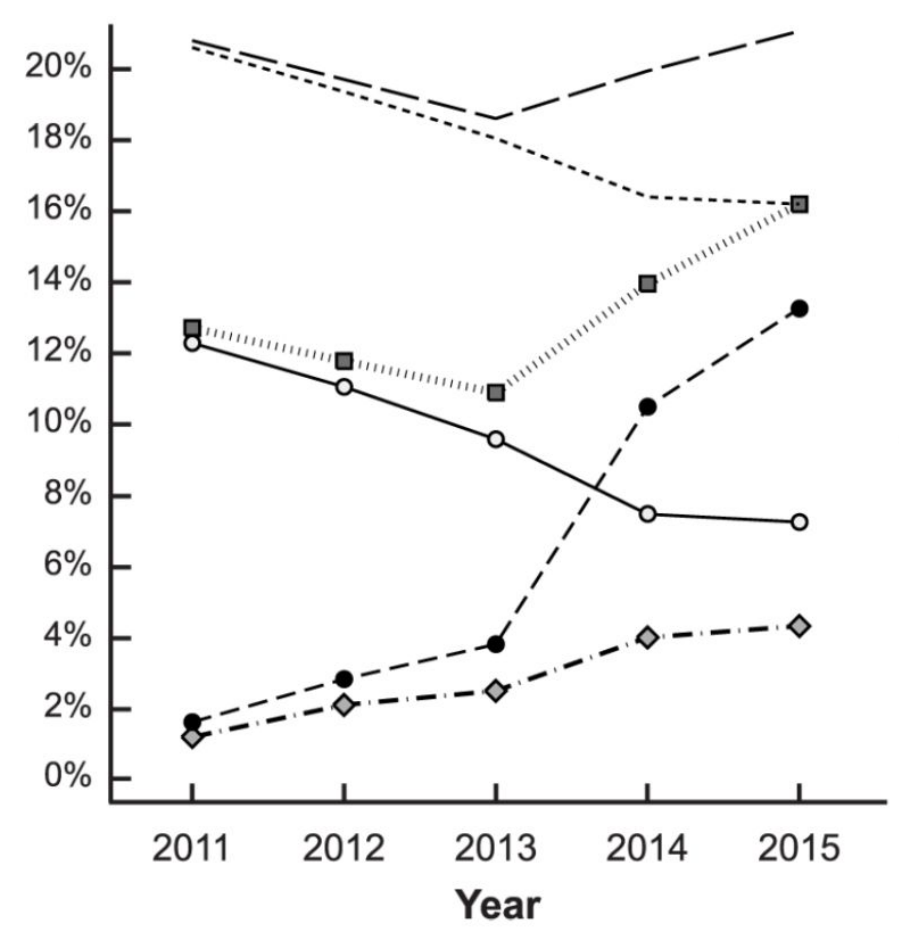

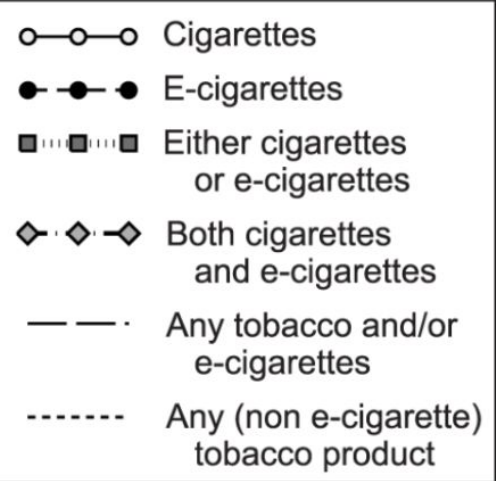
tobacco product

Prevalence of past month use of cigarettes and e-cigarettes are shown for (A) females, $N=50,034$ and (B) males, $N=50,977$. As a result of increasing e-cigarette use, the percentage of individuals using either product increased, even as cigarette use declined. "Either" refers to use of 
at least one cigarette or e-cigarette on $\geq 1$ day of the previous 30 days. "Both" refers to use of cigarettes $\geq 1$ day of the previous 30 days and use of e-cigarettes on $\geq 1$ day of the previous 30 days, not necessarily the same day. "Any" tobacco and/or e-cigarettes refers to use of $\geq 1$ of cigarettes, e-cigarettes, cigars (including little cigars and cigarillos), conventional smokeless tobacco (chewing tobacco and oral snuff), tobacco pipes, bidis, kreteks (not included in 2014 or 2015), snus, dissolvable tobacco, or hookah on $\geq 1$ day of the previous 30 days, not necessarily the same day. "Any (non e-cigarette)" product excludes e-cigarettes from the previous category. Marginal percentages adjusted across years for grade in school and race/ethnicity.

Copyright: @ 2017 Chaffee et al [15]. This is an open access article distributed under the terms of the Creative Commons Attribution License, which permits unrestricted use, distribution, and reproduction in any medium, provided the original author and source are credited. 
Figure 2. Diagram showing the complex network underlying COPD endotypes.

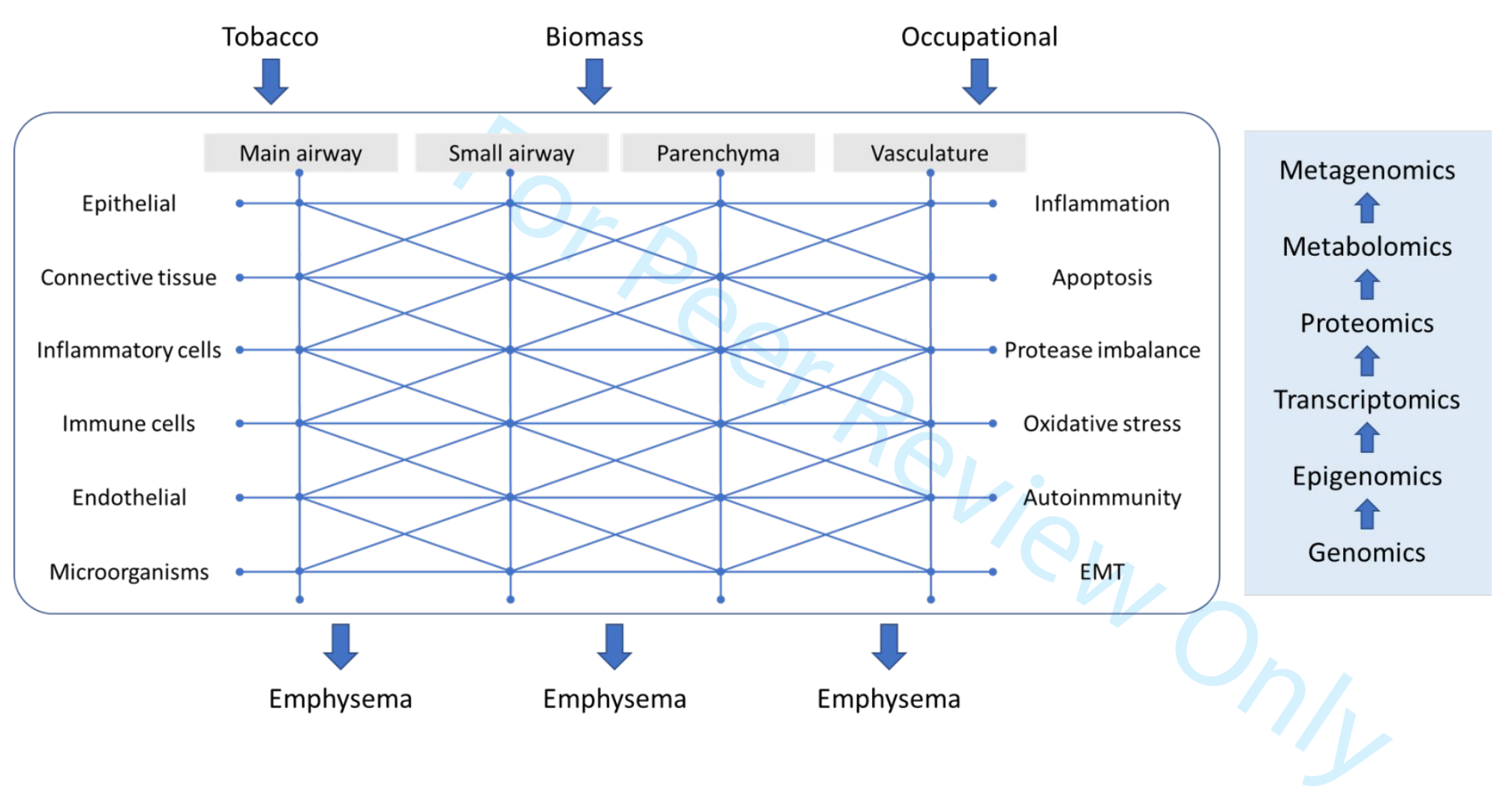

EMT: Epithelial-mesenchymal transition. The diagram represents the complex interrelation between the different anatomical locations, the participating cell types and the biological pathogenetic pathways involved. This complex network means that from exposure to different risk factors, different routes and combinations can be given to reach the same common clinical phenotype as emphysema. In this context, future 
research should use the omic techniques at each point of the network to understand the different paths that can lead to the same clinical expression. 
Figure 3. Distribution of the different mechanisms implicated in respiratory failure of stable COPD patients

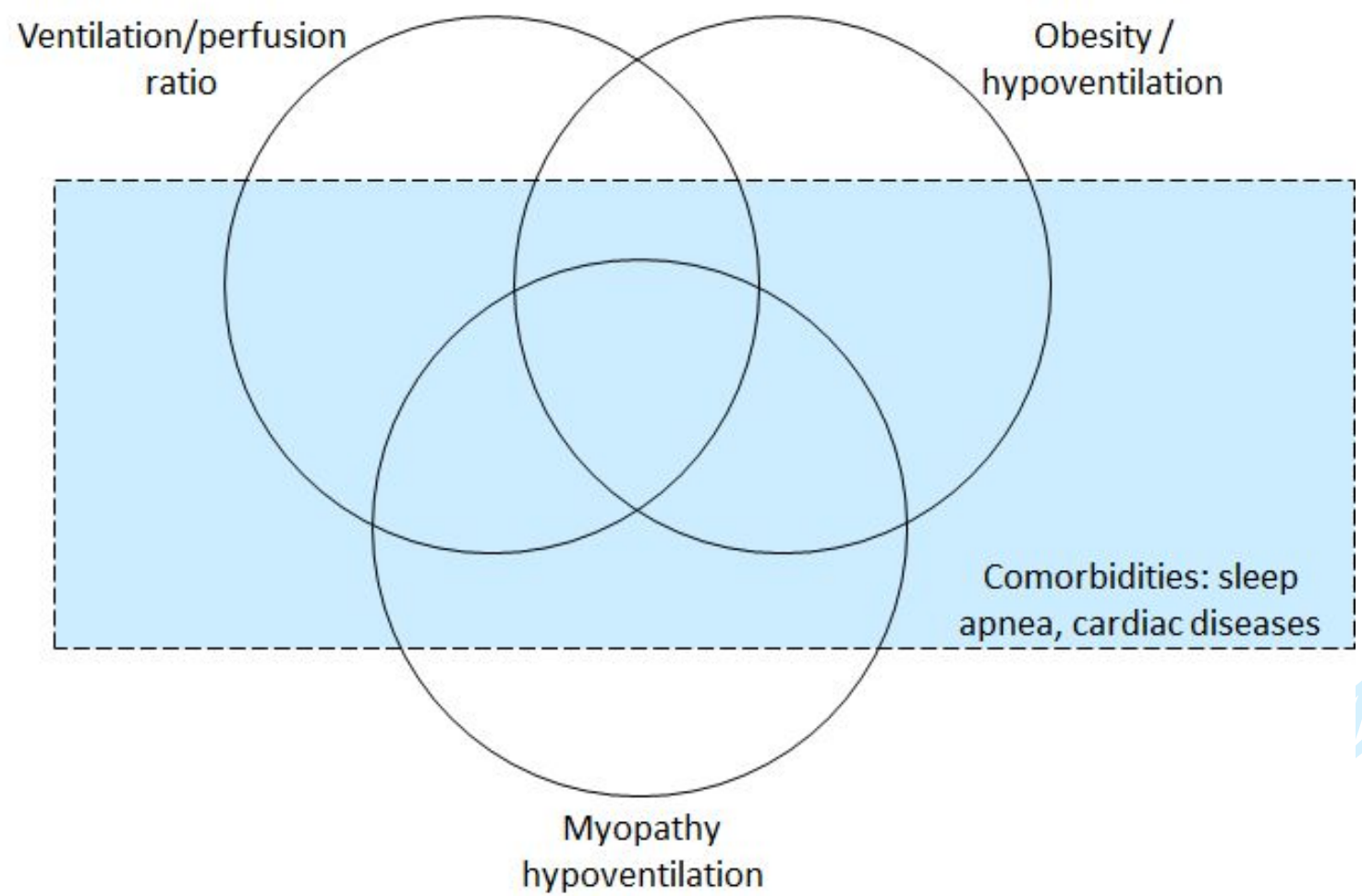

Reproduced with permission from [89]. 